Outros Tempos, vol. 18, n. 31, 2021, p. 59-86. ISSN: 1808-8031

DOI: http://dx.doi.org/10.18817/ot.v18i31.823

“QUE O ASSASSINADO NÃO TINHA RELIGIÃO, NEM CONTAVA COM DEUS PAI": escravidão, afro-catolicismo, paternalismo e criminalidade (Ilha do Quilombo, RS, 1874) ${ }^{1}$

"THAT THE MURDERER HAD NO RELIGION, NOR COUNTED ON GOD, THE FATHER": Slavery, Afro-Catholicism, paternalism and criminality (Quilombo Island, Rio Grande do Sul, 1874)

"QUE EL ASESINO NO TENÍA RELIGIÓN, NI CONTÓ CON EL PADRE DE DIOS": esclavitud, afro-catolicismo, paternalismo y criminalidad (Ilha do Quilombo, RS, 1874)

\author{
PAULO ROBERTO STAUDT MOREIRA \\ Doutor em História (UFRGS) \\ Universidade do Vale do Rio dos Sinos \\ Bolsista produtividade $\mathrm{CNPq}$ \\ São Leopoldo, Rio Grande do Sul, Brasil \\ moreirast@terra.com.br
}

\begin{abstract}
Resumo: A consciência ou opinião pública antiescravista, crescente a partir da década de 1860 e, principalmente, 1870, atingiu os tribunais e a sociedade imperial de várias maneiras. No caso que relataremos a seguir, percebemos que essa mudança de sensibilidade com relação ao escravizado tinha, também, uma intenção de sufocar ou de limitar potenciais distúrbios que, começando numa instância micropolítica senhorial, se espraiassem para dimensões maiores. Era importante valorizar as motivações dos crimes dos escravizados, ponderando se eles não teriam sido impelidos ao crime pelo mau comportamento senhorial. Além disso, nessa trama que abordaremos por meio de um documento judiciário, evidencia-se que a devoção foi um dos principais artefatos culturais que interconectou os povos aproximados pelo tráfico transatlântico, e a sua análise permite-nos perceber as formas híbridas com que se passou a captar o real e o sobrenatural, naquelas identidades e sensibilidades marcadas pela diáspora.
\end{abstract}

Palavras-chave: Escravidão. Paternalismo. Justiça. Devoção.

Abstract: The anti-slavery public consciousness, rising from the 1860 s and especially the 1870 s, hit the courts and imperial society in various ways. In the case that we will report hereafter, we perceive that this change of sensibility with respect to the enslaved also had an intention to stifle or limit potential disturbances that, starting from a micropolitical instance, would spread to larger dimensions. It was important to value the motivations of the crimes of the enslaved, pondering whether they would not have been impelled to the crime by the bad manners of their masters. Moreover, in this plot that we will approach through a judicial document, it is evident that devotion was one of the main cultural artifacts that interconnected the peoples approached by the transatlantic traffic. Its analysis allows us to perceive the hybrid forms with which the real and supernatural started to be realized, in those identities and sensibilities marked by the diaspora.

Keywords: Slavery. Paternalism. Justice. Devotion.

Resumen: La conciencia o la opinión pública contra la esclavitud, que creció desde la década de 1860 y, principalmente, 1870, llegó a los tribunales y a la sociedad imperial de varias maneras. En el caso que informaremos a continuación, nos dimos cuenta de que este cambio en la sensibilidad con relación al esclavizado, también, tenía la intención de sofocar o limitar las posibles perturbaciones que, comenzando en una instancia micropolítica señorial, se extendiesen a dimensiones más grandes. Era

\footnotetext{
${ }^{1}$ Artigo submetido à avaliação em agosto de 2020 e aprovado para publicação em dezembro de 2020.
} 
Outros Tempos, vol. 18, n. 31, 2021, p. 59-86. ISSN: 1808-8031

importante valorar las motivaciones de los crímenes de los esclavizados, considerando si habían sido impulsados al crimen por el mal comportamiento señorial. Además, en esa trama que abordaremos a través de un documento judicial, es evidente que la devoción fue uno de los principales artefactos culturales que interconectaron a los pueblos abordados por el tráfico transatlántico y su análisis nos permite percibir las formas híbridas de captación de la realidad y del sobrenatural, en aquellas identidades y sensibilidades marcadas por la diáspora.

Palabras clave: Esclavitud. Paternalismo. Justicia. Devoción.

\title{
Introdução
}

\begin{abstract}
Afirmei certa vez que uma cidade se define pela história dos seus crimes. [...] o leitor perceberá que tal sentença só se compreende quando se responde a uma questão preliminar: afinal, em que consiste, exatamente, um crime ${ }^{2}$
\end{abstract}

No ano de 1874, numa sexta-feira santa da Paixão de Cristo, um senhor de escravos foi esfaqueado e morto em uma propriedade rural situada em uma ilha localizada defronte da capital da província de São Pedro do Rio Grande do Sul. Aquele espaço geográfico era marcado toponimicamente pela presença negra escravizada e pela endêmica situação de resistência decorrente do sistema escravista vigente.

Os documentos produzidos por querelas e por contendas, que acabaram chamando a atenção da polícia e do judiciário, são imprescindíveis para a pesquisa histórica. Eles entrelaçam várias trajetórias individuais e coletivas e armazenam, em suas páginas, significados atribuídos aos acontecimentos por díspares personagens. Desde pelo menos os trabalhos clássicos de Maria Sylvia de Carvalho Franco ${ }^{3}$, Sidney Chalhoub ${ }^{4}$ e Maria Helena Machado5, para citar apenas três significativos exemplos da historiografia nacional, os documentos judiciários foram habilitados a contribuir para a pesquisa histórica, sem desconsiderar os filtros pelos quais as informações que neles consta passam. Reabilitá-los para a pesquisa histórica, entretanto, não esgota as múltiplas formas de uso dessas fontes geradas pelo funcionamento do judiciário. Historiadores como Mattos $^{6}$, Carvalho $^{7}$ e Farinatti ${ }^{8}$

\footnotetext{
${ }^{2}$ MUSSA, Alberto. A hipótese humana. Rio de Janeiro: Record, 2017. p. 8.

${ }^{3}$ FRANCO, Maria Sylvia de Carvalho. Homens livres na ordem escravocrata. São Paulo: Editora Ática, 1974. ${ }^{4}$ CHALHOUB, Sidney. Trabalho, lar e botequim. São Paulo: Brasiliense, 1986.

${ }^{5}$ MACHADO, Maria Helena. Crime e escravidão. São Paulo: Brasiliense, 1987.

${ }^{6}$ MATTOS, Hebe. Ao sul da História: lavradores pobres na crise do trabalho escravo. São Paulo: Brasiliense, 1987; Id. Nas cores do silêncio: os significados da liberdade no sudeste escravista (Brasil - século XIX). Rio de Janeiro: Prêmio Arquivo Nacional de Pesquisa, 1995.

${ }^{7}$ CARVALHO, Daniela Vallandro de. Entre a solidariedade e a animosidade: os conflitos e as relações interétnicas populares em Santa Maria - 1885-1915. 2005. Dissertação (Mestrado em História) - UNISINOS, São Leopoldo, 2005.

${ }^{8}$ FARINATTI, Luís Augusto Ebling. Confins meridionais: famílias de elite e sociedade agrária na Fronteira Sul do Brasil (1825-1865). 2007. Tese (Doutorado em História) - Universidade Federal do Rio de Janeiro, Rio de Janeiro, 2007. Ainda sobre o uso de processos judiciais na pesquisa, ver: COSTA, Yuri. Justiça infame: crime,
} 
Outros Tempos, vol. 18, n. 31, 2021, p. 59-86. ISSN: 1808-8031

apontaram que não apenas os personagens principais desses documentos podem nos guiar por nossas investigações, mas a importância de dar relevo aos coadjuvantes, inserindo neste grupo as testemunhas, aqueles e aquelas (principalmente os negros livres, forros e escravizados) chamados a dizer o que viram ou ouviram falar a respeito do acontecimento delituoso9 ${ }^{9}$

Assim, as peças judiciárias montadas na formatação de um processo criminal compõem um intrincado mosaico. São várias pessoas que, ao desempenharem funções específicas, deixam textos que são acrescentados ao processo: médicos, oficiais de justiça, advogados, intérpretes, escrivães, policiais, juízes, testemunhas, jurados. A função primária desse documento é apurar e qualificar um crime e indicar os culpados, mas a sua pretensa objetividade não produz um documento linear, antes expressa as incertezas da investigação e a participação de variados especialistas nas suas diversas fases. $\mathrm{O}$ valor dos documentos, porém, não se esgota na sua função original - primária -, mas chega até nós por seu potencial de testemunho. Os processos criminais são minas de dados - voluntária ou involuntariamente coletados -, que podem embasar análises qualitativas e mesmo quantitativas ${ }^{10}$.

A consciência ou opinião pública antiescravista, crescente a partir da década de 1860 e, principalmente, 1870, atingiu os tribunais e a sociedade imperial de várias maneiras. No caso que relataremos a seguir, percebemos que essa mudança de sensibilidade com relação ao escravizado tinha, também, uma intenção de sufocar ou de limitar potenciais distúrbios que, começando numa instância micropolítica senhorial, se espraiasse para dimensões maiores. Era importante valorizar as motivações dos crimes dos escravizados, ponderando se eles não teriam sido impelidos ao crime pelo mau comportamento senhorial. Além disso, nessa trama que abordaremos por meio de um documento judiciário, evidencia-se que a devoção foi um dos principais artefatos culturais que interconectou os povos aproximados pelo tráfico transatlântico e, a sua análise, permite-nos perceber as formas híbridas com que se

escravidão e poder no Brasil imperial. São Paulo: Alameda, 2019; FERREIRA, Ricardo Alexandre. Escravidão, criminalidade e cotidiano: Franca 1830-1888. 2003. Dissertação (Mestrado em História) - UNESP, Franca, 2003; CAMPOS, Adriana Pereira. Nas barras dos tribunais: Direito e escravidão no Espírito Santo do século XIX. 2003. Tese (Doutorado em História) - UFRJ/IFCS, Rio de Janeiro, 2003; CORRÊA, Mariza. Morte em família: representações jurídicas de papéis sexuais. Rio de Janeiro: Graal, 1983; ROSEMBERG, André. Ordem e burla: processos sociais, escravidão e justiça, Santos, década de 1880. São Paulo: Alameda, 2006.

${ }^{9}$ Muito contribuiu para a valorização dos documentos judiciários as perspectivas advindas dos experimentos microanalíticos, principalmente da vertente italiana. A respeito, ver: GINZBURG, Carlo. Mitos, emblemas, sinais: morfologia e história. São Paulo: Companhia das Letras, 1989; REVEL, Jaques. Jogos de escala: a experiência da microanálise. Rio de Janeiro: Fundação Getúlio Vargas, 1998; LEVI, Giovanni. Herança imaterial. Rio de Janeiro: Civilização Brasileira, 2000.

${ }^{10}$ GINZBURG, Carlo. Os andarilhos do bem: feitiçaria e cultos agrários nos séculos XVI e XVII. São Paulo: Cia. das Letras, 1988; GINZBURG, Carlo. Provas e possibilidades à margem de "Il ritorno de Martin Guerre", de Natalie Davis. In: GINZBURG, Carlo. A micro-história e outros ensaios. Lisboa: DIFEL; Rio de Janeiro: Bertrand Brasil, 1991. 
Outros Tempos, vol. 18, n. 31, 2021, p. 59-86. ISSN: 1808-8031

passou a captar o real e o sobrenatural, naquelas identidades e sensibilidades marcadas pela diáspora. Dessa maneira, duas questões - ou problemas - dialogam neste artigo: (i) as respostas dadas pelo campo judiciário ao aumento da resistência dos escravizados, e (ii) a forma como as crenças devocionais afro-diaspóricas aparecem involuntariamente registradas nos documentos gestados pelas apurações criminais, numa mescla entre religiosidade, crime e paternalismo.

\section{O crime}

Tradicionalmente, a Igreja Católica recomenda que a Sexta-feira Santa ou da Paixão seja um dia em que o devoto pratique a introspecção e a reflexão devocional. A espiritualidade que se estimula que se pratique nesse dia especial do calendário cristão deve inclinar o devoto ao silêncio, ao jejum e à oração. Trata-se da celebração da Paixão e da Morte do Salvador Jesus Cristo e recomenda-se que um "silêncio interior", combinado com o jejum e a abstinência da carne, ajude os fiéis na contemplação do amor de Deus, o qual "amou o mundo de tal maneira, que deu o seu Filho Unigênito, para que todo aquele que nele crê não pereça, mas tenha a vida eterna" $(\text { João, } 3,16)^{11}$. Nesse dia, a fé interdita o trabalho, as diversões e os prazeres.

Supomos que aquela sexta-feira santa, do dia 3 de abril de 1874, transcorria tranquila nas ilhas fluviais, fronteiras a cidade de Porto Alegre, capital da província de São Pedro do Rio Grande do Sul. Esporadicamente, algumas barulhentas tropas do Exército ainda entravam na capital, voltando da ocupação do Paraguai, relembrando a todos do conflito que acabara há poucos anos e reabrindo algumas feridas. Mesmo que as cicatrizes da guerra ainda fossem bem visíveis, com os soldados inválidos que caminhavam pela cidade e com excombatentes, muitos deles negros, eles ostentavam orgulhosos os bonés e insígnias de Voluntários da Pátria ${ }^{12}$. Era um dia, como vimos, que se recomendava introspecção. Mas, no arquipélago fronteiro a Porto Alegre, um triste acontecimento rompeu a aconselhada letargia.

Segundo ofício enviado pelo Delegado de Polícia ao Juiz substituto da $1^{\text {a }}$ Vara Crime, os acontecimentos desenrolaram-se, na Ilha do Quilombo, da seguinte forma:

\footnotetext{
${ }^{11}$ BÍBLIA SAGRADA. 19. ed. São Paulo: Edições Paulinas, 1965. p. 1286.

${ }^{12}$ João José Reis, em seu último livro, fala do "empoderamento" dos ex-combatentes, que voltavam da guerra do Paraguai com um intenso sentimento de orgulho, sendo protagonistas de vários conflitos, quando exigiam o reconhecimento de suas corajosas atitudes. REIS, João Josés. Ganhadores. A greve negra de 1857 na Bahia. São Paulo: Cia. das Letras, 2019. p. 251. Ver também: MOREIRA, Paulo. Voluntários negros da pátria: o recrutamento de escravos e libertos na Guerra do Paraguai. In: POSSAMAI, Paulo (org.). Gente de guerra e fronteira: estudos de história militar do Rio Grande do Sul. Pelotas: Editora da UFPEL, 2010. p. 175-198.
} 
Outros Tempos, vol. 18, n. 31, 2021, p. 59-86. ISSN: 1808-8031

\begin{abstract}
Bento José Veloso, que ai morava, vendo que na hora do almoço o seu escravo não ia comer, aproximou-se dele e lhe disse que fosse almoçar e como este lhe respondesse que não queria almoçar e percebesse o dito Veloso, não só pela recusa do denunciado, como pelo modo de falar-lhe, o propósito de contrariá-lo, incomodado como ficou, serviu-se de um ancinho e com ele deu-lhe duas pancadas. Irritado o denunciado com este procedimento, puxou de uma faca e dando com ela 3 facadas no dito Veloso, seu senhor, ocasionou-lhe a morte ${ }^{13}$.
\end{abstract}

A autoridade que redigiu o ofício acima toma, evidentemente, o partido do senhor, descrevendo o crime ocorrido como uma decorrência indevida de uma desavença que se estruturava como absolutamente normal no relacionamento esperado entre o proprietário e o seu escravizado. Certo senhor interpela seu cativo, chamando-o para a refeição, e esse se recusa, mas ao manifestar essa negativa indica, no seu modo de falar com seu proprietário, o propósito de contrariá-lo. Como desdobramento natural desse explícito desrespeito do escravizado pela autoridade senhorial, o senhor serve-se de um ancinho - instrumento de trabalho típico do cotidiano de uma unidade agrária - e dá duas pancadas naquele africano já idoso, o qual retribui a agressão com três facadas, que provocaram a morte imediata do agressor. A autoridade policial atribuiu, em seu documento, legitimidade para a violência senhorial, já que o escravizado havia desacatado o senhor com o seu atrevimento. Já o revide do escravizado parecera exagerado e injustificável, à primeira vista pelo menos.

Essa descrição da autoridade policial, atrelava-se ao ethos ou aos hábitos senhoriais bastante enraizados e que se baseavam em várias premissas, dentre elas, a submissão do trabalhador escravizado, a qual era avaliada de diferentes maneiras, uma delas era pelas expressões físicas e comportamentais, e as verbalizações dos cativos. Nesse caso de 1874, o modo de falar do cativo desvelaria o desrespeito dele com seu senhor, a sua vontade de contrariá-lo. Walter Fraga ${ }^{14}$ chama a atenção para a persistência de formas de comportamentos baseadas em ethos senhoriais específicos, lembrando que: "A escravidão foi muito mais que um sistema econômico; ela moldou condutas, definiu hierarquias sociais e raciais, forjou sentimentos, valores e etiquetas de mando e obediência”. Essas etiquetas de mando e obediência estavam em jogo (sendo reforçadas, contestadas e dissimuladas) pelos diversos agentes sociais que interagiam nesse período final do escravismo brasileiro e mesmo no pós-abolição ${ }^{15}$.

\footnotetext{
${ }^{13}$ RIO GRANDE DO SUL. Arquivo Público do Estado do Rio Grande do Sul (APERS). Processo judicial sumária no 1267 , réu: José (escravo de Bento Manoel Veloso), autor: Justiça, 1874, Porto Alegre.

${ }^{14}$ FRAGA FILHO, Walter. Encruzilhadas da liberdade. Campinas: Unicamp, 2006. p. 119.

${ }^{15}$ Ver: MOREIRA, Paulo Roberto Staudt; MATHEUS, Marcelo Santos. Processo e estrutura: o fim da escravidão e a persistência dos castigos físicos (RS, final do século XIX). Revista de História da Unisinos, v. 24, p. 269 $281,2020$.
} 
Outros Tempos, vol. 18, n. 31, 2021, p. 59-86. ISSN: 1808-8031

Como o crime representava um justiçamento procedido pelo escravizado contra o seu senhor, logo foi incurso na Lei $\mathrm{n}^{\circ} 4$, de 10 de junho de 1835, que determinava "as penas com que devem ser punidos os escravos, que matarem, ferirem ou cometerem outra qualquer ofensa física contra seus senhores, etc.; e estabelece regras para o processo"16.

$\mathrm{O}$ assassino ensaiou uma fuga, mas logo foi preso. No auto de qualificação, ele disse ter sido batizado na Igreja Católica como José, ser natural da costa da África, que morava na Ilha do Quilombo, que era solteiro e, segundo os interrogadores, representava ter 60 e tantos anos de idade. Em depoimento dado em maio do mesmo ano de 1874, o africano José acrescentou que era filho de Agebé e que trabalhava em roça e mato, indicando que se ocupava nas plantações de seu senhor e na extração de madeira. Foi interessante ele anunciar o nome de seu pai, informação essa que, raramente, encontramos em fontes primárias judiciais e policiais, parecendo que os africanos depoentes não queriam pronunciar os nomes de seus ancestrais perante as autoridades da terra dos brancos. Aliás, nesse caso específico, José só enuncia o nome paterno quando interrogado na justiça, o que pode representar um comportamento diferenciado seu com relação a essa instância específica do controle social daquela sociedade escravista.

Atualmente, a Ilha do Quilombo faz parte do Bairro Arquipélago, o qual está inserido em uma Unidade de Conservação composta da Área de Proteção Ambiental Estadual do Delta do Jacuí e do Parque Estadual do Delta do Jacuí. Esse bairro engloba território amplo, integrado por 16 ilhas, “com uma população de ocupação histórica de pescadores e de descendentes de africanos":

Segundo os moradores antigos do Arquipélago, no século XVIII as ilhas Saco do Quilombo, Maria Conga, também chamada Ilha do Quilombo (atual Ilha das Flores) e Maria Majolla (Monjolo) abrigaram ancestrais escravos. A presença de quilombo nas Ilhas é assunto ainda pendente de estudo aprofundado, porém documentos da Câmara do século XIX comprovam a presença de população negra na Ilha em 1810, e dá indícios que sua ocupação seja anterior a esta data ${ }^{17}$.

Segundo o arqueólogo Cláudio Carle, que realizou escavações sobre quilombos no local, a antiga Ilha do Quilombo teria sido incorporada à atual Ilha das Flores,

\footnotetext{
${ }^{16} \mathrm{O}$ seu artigo $1^{\mathrm{o}}$ especificava: "Serão punidos com a pena de morte os escravos ou escravas, que matarem por qualquer maneira que seja, propinarem veneno, ferirem gravemente ou fizerem outra qualquer grave ofensa física a seu senhor, a sua mulher, a descendentes ou ascendentes, que em sua companhia morarem, a administrador, feitor e ás suas mulheres, que com eles viverem. Se o ferimento, ou ofensa física forem leves, a pena será de açoutes a proporção das circunstâncias mais ou menos agravantes". RIO GRANDE DO SUL. Arquivo Histórico do Rio Grande do Sul (AHRS). Leis e Decretos do Império do Brasil, ano de 1835, livro 061. ${ }^{17}$ SOUZA, Amanda Cristina Bahi de. A presença de povos tradicionais de matrizes africanas no bairro Arquipélago: existem Quilombos nas Ilhas de Porto Alegre?. 2015. Trabalho de Conclusão (Graduação em Geografia) - Universidade Federal do Rio Grande do Sul, Porto Alegre, 2015. p. 23.
} 
Outros Tempos, vol. 18, n. 31, 2021, p. 59-86. ISSN: 1808-8031

constituindo a sua parte norte. Existem referências fragmentárias em documentos diversos, que apontam ocupações de variados formatos na Ilha. Em 1813, havia um pequeno lote de terras na Ilha do Quilombo a forra Maria Mariana. Carlos Antônio Vieira, inventariado em 1882, possuía uma chácara na Ilha do Quilombo, no Rio Guaíba ${ }^{18}$. Ainda hoje existe o arroio (ou canal) da Maria Conga, que separa a Ilha da Casa da Pólvora da Ilha das Flores.

A revelia de ser um dia santo, o conflito ocorrido na Ilha do Quilombo se deu em um momento de labuta, sendo presenciado por vários homens que ali, naquele momento, trabalhavam juntos. O português Antônio Couto Fernandes da Mota, de 27 anos, morador da Ilha do Quilombo, no arroio da Maria Conga, contou que era empregado (peão) da casa do senhor falecido e, ao meio-dia daquela sexta-feira santa, estava em companhia de Bruno Francisco Martins, "perto do lugar onde o assassinado costuma mandar queimar carvão" e que viu e ouviu Bento José Veloso dizer ao seu escravizado José:

[...] negro, vai almoçar e o negro gritando respondeu que não queria almoçar; em vista do que, Bento [...] deu algumas pancadas com um ancinho de ferro no dito escravo, e este, puxando da faca, deu-lhe 3 facadas, não tendo ele respondente ido capturar o negro, por ter sido necessário prestar socorros ao ferido, depois deste morto seguiu a chamar o Inspetor de Quarteirão Luiz Antônio Rolim, para tomar conhecimento, tendo o mesmo dado providências para conduzir o cadáver para a cidade. $^{19}$

Em outro depoimento, o depoente Bruno Francisco Martins, citado acima, acrescenta que Bento Manoel Veloso estava na ocasião "já embriagado e cambaleando". Os demais depoimentos seguiram na mesma linha dos anteriores, até que o réu depôs, apresentando uma versão não exatamente diferente, mas explicando quais foram as suas motivações para aquela explosão homicida. Disse o africano José:

[...] que matou seu senhor [...] por continuamente maltratar os escravos, tanto assim que matou 4, de nomes Belisário, Adão, Domingos e Vicente, sendo este último enforcado na Capela. Que o assassinado não tinha religião, nem contava com Deus Pai, que na sexta-feira santa, querendo ele respondente guardar o jejum, foi por esse motivo atrozmente espancado pelo dito seu senhor, tendo então perdido a paciência e assassinou-o nesse ato.[Sobre os negros assassinados] Disse que todos foram assassinados por bordoadas, que Adão morreu de uma pancada de olho de enxada na cabeça; o Belizário com uma pancada de "mão" de pilão; Domingos com

\footnotetext{
${ }^{18}$ CARLE, Cláudio Baptista. A Organização Espacial dos Assentamentos de Ocupação Tradicional de Africanos e Descendentes no Rio Grande do Sul, nos Séculos XVIII e XIX. 1991.Tese (Doutorado Internacional em Arqueologia) - Pontifícia Universidade Católica, Porto Alegre, 2005. p. 48 e 56; GOMES, José; MACHADO, Helena, VENTMIGLIA, Marise. Arquipélago: As Ilhas de Porto Alegre, memórias dos bairros. Porto Alegre: Unidade Editorial, PMPA, 1995. p. 31. APERS - $1^{\circ}$ Cartório do Cível de Porto Alegre, maço 20, nº 451, 1882; PICCOLO, Helga L. A resistência escrava no Rio Grande do Sul. Cadernos de Estudos, n. 6, Porto Alegre: UFRGS, Curso de Pós-Graduação em História, p. 3, 1991.

${ }^{19}$ RIO GRANDE DO SUL. Arquivo Público do Estado do Rio Grande do Sul (APERS). Processo judicial sumária nº 1267, réu: José (escravo de Bento Manoel Veloso), autor: Justiça, 1874, Porto Alegre.
} 
Outros Tempos, vol. 18, n. 31, 2021, p. 59-86. ISSN: 1808-8031

pancadas de remo de pá, sendo depois o cadáver atirado ao rio, e que Vicente [...] foi enforcado com um laço. (grifos nossos). ${ }^{20}$

Quanto ao escravizado assassinado Adão, citado acima, José contou que ele próprio, mandado por seu senhor, fez o enterro de seu parceiro e que o feitor e um indivíduo chamado Bruno sabiam disso. As autoridades levaram a sério o depoimento, talvez pela riqueza de detalhes que era composto. Assim, em 7 de abril de 1874, foi feito um auto de exumação, "no lugar denominado Rio dos Sinos, na fazenda de Berto Círio, no lugar que serve de cemitério aos moradores daquelas redondezas". A Fazenda de campos e matos de Berto Círio ficava na margem direita do rio dos Sinos, no $3^{\circ}$ distrito da freguesia de Santana, na época pertencente ao município vizinho de São Leopoldo. Sua produção baseava-se na agropecuária, possuindo ainda uma ótima olaria e atafona, sendo a sede da fazenda instalada em um sobrado de dois andares, de frente para o rio, tudo de tijolos e coberto de telha ${ }^{21}$.

Hoje em dia a região desse cemitério localiza-se no município de Nova Santa Rita, o qual possui um bairro chamado Berto Círio, não longe das margens do rio dos Sinos. Esse cemitério deve ter começado com enterros de pessoas da própria família do proprietário, além de seus agregados e escravizados, mas após algum tempo indivíduos da redondeza começaram a ali enterrar seus mortos. Não parece ser um campo santo irregular, mas seu caráter privado devia permitir que cadáveres fossem ali sepultados de forma incógnita, ainda mais por ser de fácil acesso, já que localizado na margem de um dos rios que desaguam no lago Guaíba, que banha Porto Alegre. O Delegado de Polícia da capital da província, Feliciano Joaquim de Borman, acompanhou a exumação e, na ocasião, ordenou ao réu José e a Bruno Francisco Martins que indicassem o lugar onde, há 15 meses, fora enterrado o escravizado Adão. Sendo indicado o mesmo local pelos dois, foi então aberta uma sepultura e "exumado um esqueleto de homem, que se achava lançado na sepultura sem caixão". Feito auto de corpo de delito na delegacia, constatou-se que o cadáver era humano, de homem, de cor preta.

A partir desse momento, os depoimentos se complexificaram, com as testemunhas sendo indagadas sobre o homicídio de Bento José Veloso, mas também sobre o tratamento dado

\footnotetext{
${ }^{20}$ RIO GRANDE DO SUL. Arquivo Público do Estado do Rio Grande do Sul (APERS). Processo judicial sumária $n^{\circ} 1267$, réu: José (escravo de Bento Manoel Veloso), autor: Justiça, 1874, Porto Alegre.

${ }^{21}$ Nos baseamos na penhora dos bens de Berto Círio, por dívidas, ocorrida em dezembro de 1874 . Na época ele tinha cinco escravizados maiores de 50 anos. Não conseguimos descobrir quem ficou com as propriedades e benfeitorias. (APERS - Juízo de Direito da $1^{\text {a }}$ Vara e do Cível de Porto Alegre, Execução, maço 85, auto 1969, executante: Fortunato Ferreira Ramos, Executado: Berto Cirio, 1874; APERS - $1^{\circ}$ Cartório do Cível de Porto Alegre, Execução, maço 85, auto 1967, executante: Eduardo de Azevedo e Souza Filho, Executado: Berto Cirio, Luiz Terragno e Pedro Miranda Lucy, 1874).
} 
Outros Tempos, vol. 18, n. 31, 2021, p. 59-86. ISSN: 1808-8031

por esse senhor aos seus escravizados, e ao destino daqueles que José alegava terem sido assassinados pela fúria senhorial. O citado lavrador, Bruno Francisco Martins, jornaleiro de 24 anos, natural desta província, contou:

[...] que a morte do preto Adão teve lugar pouco tempo depois de sua chegada a Ilha de Bento Manoel Veloso, que, quando por ai foi trabalhar, já encontrou o negro bastante doente e que os seus parceiros em geral diziam que a doença era originada de fortes castigos que o escravo Adão teria recebido, mas que ele respondente não presenciou estes castigos [...] que sendo encarregado da casa, recebeu ordem de Bento [...] para ir ajudar a enterrar no Rio dos Sinos, no cemitério que existe na fazenda de Berto Círio, o cadáver do preto Adão [...] não examinou o cadáver. ${ }^{22}$

Sobre o escravizado Domingos, o jornaleiro Bruno, que deveria trabalhar junto com os cativos daquela propriedade, contou que a sua morte ocorreu antes de sua chegada naquela ilha:

[...] mas que recorda-se perfeitamente que o cadáver deste preto apareceu na ponta das pedras, junto ao quartel da [artilharia] e que ele respondente foi um dos que ajudou com alguns soldados do mesmo corpo a tirar o cadáver para fora do rio, e o crânio do cadáver estava partido, que os médicos examinando disseram que tinha morrido afogado, julgando que a cabeça estaria quebrada por bater o cadáver com ela nas pedras. ${ }^{23}$

Desconfiado e esperto, sabedor dos hábitos comunitários e da dinâmica social daquela cidade, o Delegado perguntou a Bruno se ele sabia a razão de Bento Manoel Veloso, sendo residente no $1^{\circ}$ distrito dessa capital, com moradia "muito mais vizinha desta cidade, deixar de vir enterrar o cadáver do preto Adão no cemitério desta cidade, para ir dar uma volta tamanha e tão distante, mandando realizar o enterro na fazenda de Berto Círio, no Rio dos Sinos?". Com isso, o delegado destacava como incriminatório ou, no mínimo, suspeito, o fato de Bento Manoel Veloso não ter procurado as autoridades da cidade de Porto Alegre e sepultado seu escravizado no cemitério local, administrado pela Santa Casa de Misericórdia. ${ }^{24}$ A testemunha Bruno sucintamente respondeu que ignorava o motivo, mas a suspeita do assassinato estava nada sutilmente registrada nos autos pelo delegado. Sobre as causas das mortes daqueles escravizados citados no depoimento do réu africano José, Bruno também diz

\footnotetext{
${ }^{22}$ RIO GRANDE DO SUL. Arquivo Público do Estado do Rio Grande do Sul (APERS). Processo judicial sumária no 1267 , réu: José (escravo de Bento Manoel Veloso), autor: Justiça, 1874, Porto Alegre.

${ }^{23}$ RIO GRANDE DO SUL. Arquivo Público do Estado do Rio Grande do Sul (APERS). Processo judicial sumária no 1267, réu: José (escravo de Bento Manoel Veloso), autor: Justiça, 1874, Porto Alegre.

${ }^{24}$ Sobre o cemitério de Porto Alegre e as práticas de enterramento, ver: MEIRELLES, Pedro von Mengden. Um terreno cheio de asperezas: o cemitério da matriz de Porto Alegre no cotidiano da cidade (1772-1888). 2016. Dissertação (Mestrado em História) - Universidade Federal do Rio Grande do Sul, Porto Alegre, 2016; NASCIMENTO, Mara Regina do Nascimento. Irmandades Leigas em Porto Alegre. Práticas funerárias e experiência urbana (séculos XVIII-XIX). Tese (Doutorado em História) - Universidade Federal do Rio Grande do Sul, 2006; MÜLLER, Liane Susan. As contas do meu rosário são balas de artilharia. Porto Alegre: Pragmatha, 2013.
} 
Outros Tempos, vol. 18, n. 31, 2021, p. 59-86. ISSN: 1808-8031

que não sabia, "mas que os parceiros desses escravos pertencentes a Bento [...] atribuem a excessivos castigos recebidos pelo falecido", e acrescentou que o cadáver de Adão foi embarcado à meia-noite numa canoa e que quando ia ser enterrado, "deitou pela boca porção de sangue preto".

O sargento do Corpo Policial, Antônio Joaquim Silveira, de 49 anos e natural de Porto Alegre, foi o comandante da força que capturou o réu e contou que ouviu dos habitantes das ilhas que o senhor chacinado pelo africano José, tinha um modo bárbaro de castigar os seus escravizados, e que o motivo do conflito que acabou no homicídio teria sido uma discussão a respeito do jejum da Sexta-feira Santa. O lavrador, Floriano do Espírito Santo, de 49 anos e morador na Ilha do Quilombo, vizinho a propriedade de Bento Manoel Veloso, contou que sabia que o escravizado Adão estava "muito doente, mas que ignorava a causa da doença". Logo que o cativo Adão faleceu, Floriano do Espírito Santo, como amigo de Veloso, que se achava ausente da ilha, foi até a cidade comunicá-lo e voltou com ele para providenciar o enterro, "que teve lugar no outro dia, saindo o cadáver da ilha a meia-noite". Floriano também confirmou ter saído sangue da boca do cadáver, quando do sepultamento.

O londrino João Pedro Robles, com a idade avançada de 80 anos, vivia como lavrador em terras localizadas na ilha de propriedade de Bento Manoel Veloso. Pelo depoimento que ele deu, parece que era um agregado de Veloso, com produção agrícola própria, mas prestando serviços ocasionais a Veloso, senhor de fato das terras e da escravaria. Indagado sobre o escravizado Domingos, ele contou:

Disse que ia em companhia de Bento [...] e o citado preto Domingos, embarcados em uma canoa, e que chegando na boca do Rio Jacuí, Veloso incomodado com o preto, levantou-se armado de um remo de pá, com o qual arremessou-lhe uma pancada tão forte que batendo o remo na borda da canoa partiu-se, que Veloso enfurecido agarrou um cabo para castigar o negro, mas que este ou por perda do equilíbrio ou por medo, caiu na água e não sabendo nadar afogou-se, que Bento seguindo viagem, foi dar parte a um inspetor de quarteirão da (Ilha da) Pintada (grifos nossos). ${ }^{25}$

O inspetor de quarteirão Luiz Antônio Rolim, citado em vários depoimentos, faleceu em 11 de janeiro de 1903 e no inventário procedido por sua viúva Angélica Alvarina Rolim, ainda encontramos imóveis nas ilhas fronteiras da capital: uma casa de moradia na Ilha denominada Boca dos Três Rios e uma propriedade avaliada em seis contos de réis na Ilha do arroio Formoso, na Boca dos Três Rios. Os três rios referidos são os formadores da bacia

\footnotetext{
${ }^{25}$ RIO GRANDE DO SUL. Arquivo Público do Estado do Rio Grande do Sul (APERS). Processo judicial sumária $n^{\circ} 1267$, réu: José (escravo de Bento Manoel Veloso), autor: Justiça, 1874, Porto Alegre.
} 
Outros Tempos, vol. 18, n. 31, 2021, p. 59-86. ISSN: 1808-8031

hidrografia do Lago Guaíba, que banha e justifica a importância geo-histórica de Porto Alegre, são eles o Sinos, o Caí e o Jacuí ${ }^{26}$.

Os Inspetores de Quarteirão eram figuras importantes na capilaridade da atividade policial, sendo geralmente escolhidas pessoas que, por suas atividades comerciais (donos de casas de negócio, por exemplo) ou tempo de residência no local, conheciam os habitantes, podendo emitir opiniões sobre os seus hábitos ou obter com facilidade informações a respeito dos moradores. O cargo surgiu juntamente com a lei de 15 de outubro de 1827, que criou o cargo de Juiz de Paz e determinou que essa autoridade $\left(\S 15^{\circ}\right)$ deveria "Dividir o distrito em quarteirões, que não conterão mais de 25 fogos; e nomear para cada um deles um Oficial, que o avise de todos os acontecimentos, e execute suas ordens". Cinco anos depois, o Código de Processo Criminal, aprovado por lei imperial de 29.11.1832, ao descrever "as pessoas encarregadas da Administração da Justiça Criminal, nos Juízos de Primeira Instância" informou: “Art. 4 Haverá em cada Distrito um Juiz de Paz, um Escrivão, tantos Inspetores, quantos forem os Quarteirões, e os Oficiais de Justiça, que parecerem necessários”. Finalmente, a lei $\mathrm{n}^{\mathrm{o}}$ 261, de 03.12.1841, que reformou o Código do processo Criminal, vinculou os Inspetores de Quarteirão aos subdelegados de polícia (artigo $9^{\circ}$ ). Tratava-se de cargo não remunerado que visava a prevenção de crimes, a prisão de criminosos em flagrante delito, a obtenção de informações confiáveis sobre os envolvidos em delitos diversos ${ }^{27}$. O depoimento do inspetor de quarteirão Luiz Antônio Rolim, realmente, foi importante e ele foi chamado em mais de uma oportunidade para se pronunciar. Segundo ele:

[...] era geral a fama dos maus tratos que Bento [...] dava a seus escravos, que muito tempo depois da morte de um dos escravos [...] uma vizinha de Bento [...] disse a mulher dele respondente ter sabido que Bento [...] havia dado uma sova tão grande em um escravo, que disso tinha o escravo morrido. Que é verdade que Bento [...] lhe foi uma ocasião pedir para que desse um atestado, a bem de poder enterrar um escravo, ao que ele respondente disse que só passaria o atestado depois de examinar o cadáver em presença de duas testemunhas, ao que Bento se recusou, ficando muito incomodado, disse que ele mesmo passava o atestado e não precisava Inspetor de Quarteirão, e que vindo a cidade, um subdelegado se prestou a mandar outro Inspetor de Quarteirão a passar atestado. ${ }^{28}$

Talvez, tratando-se de um senhor e vizinho já falecido, o inspetor de quarteirão Rolim e as outras testemunhas se sentiram mais à vontade para falar abertamente, mas as tintas fornecidas pelos depoimentos pintavam aquele acontecimento da páscoa, de 1874, com

\footnotetext{
${ }^{26}$ APERS. Juízo de Órfãos de Porto Alegre, inventário nº 2529.

${ }^{27}$ Sobre os juízes de paz, ver: FLORY, Thomas. El juez de paz y el jurado en el Brasil imperial. México: Fondo de Cultura Económica, 1986.

${ }^{28}$ RIO GRANDE DO SUL. Arquivo Público do Estado do Rio Grande do Sul (APERS). Processo judicial sumária n 1267, réu: José (escravo de Bento Manoel Veloso), autor: Justiça, 1874, Porto Alegre.
} 
Outros Tempos, vol. 18, n. 31, 2021, p. 59-86. ISSN: 1808-8031

outras cores. O desprestígio da escravidão naquele período, mesmo que ainda faltassem 14 anos para a abolição definitiva, fazia com que o assassinato de um senhor de escravos por seu escravizado fosse visto de forma bem mais complexa do que, usualmente, se esperaria de uma sociedade escravista. ${ }^{29}$ Suspeitava-se que o comportamento homicida do cativo fosse um reflexo dos exageros cruéis do senhor falecido, que não gerenciava sua propriedade humana de uma maneira adequada e, ao se comportar assim, fragilizava e colocava em risco a segurança de seus vizinhos. No depoimento acima, vemos que o inspetor de quarteirão menciona conversas entre os vizinhos sobre a imperícia e perversidade do senhor Veloso no trato de seus cativos. Além disso, ele conta que se negou a passar um atestado para que aquele senhor enterrasse um cativo que expirara por motivos escusos e como isso provocara a ira e descontentamento do senhor, que parecia ainda reger-se por um ethos senhorial, no qual ele ainda era a única autoridade a se considerar no governo da vida de seus cativos.

O delegado de polícia Bormann, em 9 de abril de 1874, escreveu seu parecer dizendo que estava provado que devido ao "injusto castigo", o preto José agrediu seu senhor com uma faca, matando-o. Capturado 48 horas depois, o réu confessou o crime, dizendo que assim agiu para evitar "o injusto castigo que sofria" e, também, por "recear que o seu senhor o matasse a tormentos, como já tinha praticado nos escravos seus parceiros, de nomes Belisário, Adão, Domingos e Vicente, sendo o cadáver de Belisário enterrado nesta cidade, protegido por um atestado falso".

$\mathrm{Na}$ justiça, os depoimentos seguiram a mesma linha dos acima citados, mas duas testemunhas destacaram o fato de que o africano José era figura bem quista naquela hierarquia de senzala ${ }^{30}$. O pescador Frederico de Barros Leitão, morador das ilhas e com 42 anos, contou que ouviu gritos na Sexta-feira da Paixão e, por isso, foi a casa do finado Veloso. Disse que não sabia se ele era exagerado no castigo dos seus escravizados, "mas que ouvia dizer que o preto José era o escravo de sua confiança”. O inglês João Pedro Roble, já citado anteriormente, narrou que "o finado era rigoroso com os escravos, mas que José era seu fiel”.

Essas duas testemunhas são as únicas que salientam que a relação do africano e de seu senhor Veloso seria mediada pelo favorecimento e pela confiança por parte do senhor, que, em contrapartida, recebia a fidelidade e a eficiência laboral do cativo. Isso endossa uma

\footnotetext{
${ }^{29}$ Ver: GENOVESE, Eugene. A Terra Prometida I: o mundo que os escravos criaram. Rio de Janeiro: Paz e Terra, 1979; MACHADO, Maria Helena. O plano e o pânico: os Movimentos Sociais na década da abolição. Rio de Janeiro: Editora UFRJ, EDUSP, 1994; CHALHOUB, Sidney. Visões da liberdade: uma história das últimas décadas da escravidão na corte. São Paulo: Companhia de Letras, 1990. Sobre o abolicionismo: ALONSO, Angela. Flores, votos e balas: o movimento abolicionista brasileiro (1868-88). São Paulo: Companhia das Letras, 2015.

${ }^{30}$ ENGEMANN, Carlos. De laços e de nós. Rio de Janeiro: Apicuri, 2008.
} 
Outros Tempos, vol. 18, n. 31, 2021, p. 59-86. ISSN: 1808-8031

visão que muitos queriam ter e manter das relações escravistas, e que talvez tomasse relevo em um momento em que, como já dissemos, era difícil justificar moralmente a manutenção dessa forma de trabalho compulsório. Segundo o historiador inglês E. P. Thompson, o "paternalismo sugere calor humano, numa relação mutuamente consentida; o pai tem consciência dos deveres e responsabilidades para com o filho, o filho é submisso ou complacente na sua posição filial"31. Segundo Hebe Mattos, "o segredo do código paternalista de dominação escravista estava no poder senhorial de transformar em concessão toda e qualquer ampliação do espaço de autonomia dentro do cativeiro"32. O historiador Sidney Chalhoub alerta, entretanto, que "a vigência de uma ideologia paternalista não significa a inexistência de solidariedades horizontais e, por conseguinte, de antagonismos sociais" ${ }^{\prime 3}$. Ou seja, os códigos paternalistas só podem ser entendidos se analisados relacionalmente, sendo criados e mantidos por (tensos) consensos sociais, barganhados por grupos de indivíduos situados desigualmente nas hierarquias econômicas, políticas e étnico-raciais.

\section{Uma unidade produtiva na Ilha do Quilombo}

Salientamos no início deste artigo o fato de que o nosso observatório social era um documento judiciário, gestado pelas autoridades responsáveis pelo controle social, para a apuração de um acontecimento criminoso. Isso, certamente, não prescreve que a sua análise prescinda do cruzamento com outros documentos. A história social, em um salutar diálogo com a microanálise, tem advogado que o pesquisador procure os seus personagens em suportes documentais diferentes, seguindo métodos indiciários e pistas nominais ${ }^{34}$. Daí o recurso a inventários post-mortem, registros eclesiásticos (batismo, morte, casamento), correspondências administrativas, etc ${ }^{35}$.

\footnotetext{
${ }^{31}$ THOMPSON, Edward Palmer. Costumes em comum: estudos sobre a cultura popular tradicional. São Paulo: Companhia das Letras, 1998. p. 29.

${ }^{32}$ MATTOS, Hebe. Das cores do silêncio: os significados da liberdade no sudeste escravista - Brasil, século XIX. 3. ed. Campinas: Editora da Unicamp, 2013. p. 160.

${ }^{33}$ CHALHOUB, Sidney. Machado de Assis Historiador. São Paulo: Companhia das Letras, 2003. p. 46.

${ }^{34}$ CASTRO, Hebe Mattos de. História social. In: CARDOSO, Ciro Flamarion; VAINFAS, Ronaldo (org.). Domínios da história: ensaios de teoria e metodologia. Rio de Janeiro: Campus, 1997; GINZBURG, Carlo; PONI, Carlo. O nome e o como: troca desigual e mercado historiográfico. In: Carlo Ginzburg (org.). A microhistória e outros ensaios. Rio de Janeiro: Bertrand Brasil, 1991; LORIGA, Sabina. A biografia como problema. In: REVEL, Jacques (org.). Jogos de escalas: a experiência da microanálise. Rio de Janeiro: Editora Fundação Getúlio Vargas, 1998.

${ }^{35}$ FRAGOSO, João; GUEDES, Roberto; SAMPAIO, Antônio Carlos Jucá de (org.). Arquivos paroquiais $e$ história social na América Lusa: métodos e técnicas de pesquisa na reinvenção de um corpus documental, séculos XVII e XVIII. Rio de Janeiro: Mauad X, 2014; GUEDES, Roberto; FRAGOSO, João (org.). História social em registros paroquiais: Sul-Sudeste do Brasil, séculos XVIII-XIX. Rio de Janeiro: Mauda, 2016.
} 
Outros Tempos, vol. 18, n. 31, 2021, p. 59-86. ISSN: 1808-8031

$\mathrm{O}$ assassinato de Bento Manoel Veloso obrigou a sua viúva a proceder o seu inventário post-mortem, o que beneficiou a pesquisa, fornecendo dados consistentes sobre o cenário do crime, o cotidiano produtivo daquela propriedade, a genealogia dos senhores e os parceiros escravizados do cativo homicida ${ }^{36}$.

O casal Silvana Maria do Rosário e Bento Manoel Veloso tinha dois filhos: Bento Manoel Veloso Filho (com 18 anos) e Joaquim Manoel Veloso (com 16 anos). O primogênito nasceu em 17 de dezembro de1856 e só foi batizado na Igreja de Nossa Senhora do Rosário, em Porto Alegre, dois anos depois, em 12 de junho de 1858. O segundo filho, Joaquim, foi batizado em 04 de junho de1860, no mesmo templo do irmão, tendo nascido em 26 de abril do ano anterior. Os dois batizandos foram registrados por dois padres diferentes, como filhos naturais de Bento Manoel Veloso e da porto-alegrense Silvana Maria do Rosário. Ou seja, o casal não sacramentou a sua relação na Igreja Católica mas, mesmo assim, as autoridades eclesiásticas anotaram o nome de ambos progenitores, o que não era prática eclesiástica muito comum e indica que Bento e Silvana tinham certo prestígio social comunitário. Os batizandos tiveram em seus registros de batismo anotados os nomes dos avós paternos - Francisco Manoel Veloso e Anastácia de Amoedo (naturais de Portugal) -, mas os avós maternos eram ignorados. Aliás, Silvana aparece como do Rosário, mas no inventário de seu amásio ela ostenta o sobrenome Veloso, e ela e seus filhos recebem a herança sem qualquer impedimento, mesmo que o falecido tenha morrido abintestado ${ }^{37}$. O fato daquela relação longeva não ter sido sacramentada na Igreja, a invisibilidade genealógica dos avós maternos, a frequência do casal e dos filhos na Paróquia do Rosário de grande circulação de pessoas nãobrancas, a adoção por Silvana do sobrenome do Rosário (muito comum em famílias egressas do cativeiro $)^{38}$, nos faz suspeitar (com bases um tanto frágeis) que Dona Silvana Maria do Rosário fosse uma mulher negra (ou parda), talvez egressa do cativeiro.

\footnotetext{
${ }^{36}$ APERS. Juizado de Órfãos de Porto Alegre, inventário $\mathrm{n}^{\circ}$ 474, inventariado: Bento Manoel Velloso, inventariante: Silvana Maria Veloso, ano: 1874.

${ }^{37} \mathrm{O}$ primeiro rebento (Bento) foi apadrinhado por Joaquim Antônio de Campos (solteiro) e amadrinhado por Nossa Senhora e o segundo (Joaquim) foi levado a pia batismal pelo casal Joaquim Moreira de Mendonça e sua mulher Maria Nunes de Mendonça. ARQUIVO HISTÓRICO DA CÚRIA METROPOLITANA DE PORTO ALEGRE (AHCMPA). Livro $3^{\circ}$ de Batismos de Livres da Paróquia de Nossa Senhora do Rosário, folhas 85 e 165).

${ }^{38}$ Sobre as práticas nominativas de famílias egressas do cativeiro, ver: WEIMER, Rodrigo de Azevedo. Felisberta e sua gente: consciência histórica e racialização em uma família negra no pós-emancipação riograndense. Rio de Janeiro: Editora FGV, 2015; WEIMER, Rodrigo de Azevedo. Os nomes da liberdade: exescravos na serra gaúcha no pós-abolição. São Leopoldo: Oikos, 2008; CAMILO, Nathan. É preferível bom nome a muitas riquezas: dinâmica das práticas de nominação no extremo sul do Brasil entre o final do século XVIII e o início do século XIX. 2016. Dissertação (Mestrado em História) - Universidade do Vale do Rio dos Sinos, São Leopoldo, 2016.
} 
Outros Tempos, vol. 18, n. 31, 2021, p. 59-86. ISSN: 1808-8031

A identificação mais pormenorizada do senhor assassinado foi conseguida em outro processo judicial, mas desta vez Bento Manoel Veloso era o réu e não a vítima do acontecimento delituoso. Das 22 para as 23 horas da noite, do dia 9 de maio de 1851, no Beco do João Coelho (atual Travessa Acilino de Carvalho, centro de Porto Alegre, entre as ruas Andradas e Andrade Neves), alguns homens procuravam companhia feminina. O mais esclarecedor depoimento foi dado pela parda Clarinda Maria Francisca da Conceição, justamente, uma das mulheres disputadas por aqueles machos agressivos e competitivos. Clarinda, chamada nos depoimentos como Clara, tinha 20 anos, nascera nessa província, era solteira, analfabeta e vivia do seu trabalho. Ela conta que estava na janela de sua casa quando chegou um indivíduo chamado João Carmo que quis entrar no seu domicílio, e ela não consentiu, mas mesmo assim ele pulou a janela e acomodou-se sentado na sala. A desfaçatez desse homem em invadir e instalar-se na casa de uma provável prostituta, sem a autorização da dona da casa, mostra como essas residências situavam-se entre a casa e a rua, sendo um local dúbio, entre o público e o privado ${ }^{39}$. Chegou depois Bento Manoel Veloso e fícou conversando com Clara pela janela, mas logo percebeu que outro homem ali estava, no interior da moradia. Bento, então, desafiou João Carmo a sair e esse lhe disse "que saia como homem" e se "atracaram a pulso".

João do Carmo foi derrotado na peleja e tratou de curar o seu orgulho ferido queixando-se na polícia e, ainda, acusando Bento de tê-lo assaltado. Bento foi preso pela polícia naquela mesma noite, acoutado que estava na casa defronte a de Clara, onde morava Josefa Maria da Conceição, de cor branca, 20 anos de idade, também nascida nessa província, solteira, analfabeta e que também dizia viver de seu trabalho. No auto de qualificação produzido no dia seguinte ao conflito, o réu Bento Manoel Veloso apresentou-se como filho de Francisco Manoel Veloso, ter 26 a 27 anos, solteiro, vivia de negócios, natural da Espanha, nascido e batizado no Bispado de Tui e que sabia ler e escrever. A cidade de Tui fica exatamente na fronteira entre Portugal e Espanha, na região da Galiza, o que justifica que esse

\footnotetext{
${ }^{39}$ AREND, Silvia Maria Fávero. Amasiar ou casar? a família popular no final do século XIX. Porto Alegre: Editora Universidade, UFRGS, 2001; BORDIEU, Pierre. A dominação masculina: a condição feminina e a violência simbólica. Rio de Janeiro: BestBolso, 2016; CAULFIELD, Sueann. Em defesa da honra: moralidade, modernidade e nação no Rio de Janeiro (1918 - 1940). Campinas, SP: Editora da Unicamp, 2000; ENGEL, Magali. Meretrizes e doutores: saber médico e prostituição no Rio de Janeiro (1840 - 1890). São Paulo: Brasiliense, 2004; GARZONI, Lerice de Castro. Vagabundas e conhecidas: novos olhares sobre a polícia republicana (Rio de Janeiro, início século XX). 2007. Dissertação (Mestrado em História)- Universidade de Campinas, Campinas, 2007; PEREIRA, Cristiana Schettini. Que tenhas teu corpo: uma história social da prostituição no Rio de Janeiro das primeiras décadas republicanas. 2002. Tese (Doutorado em História) Unicamp, Campinas, 2002; ALMALEH, Priscilla. Ser mulher: cotidianos, representações e interseccionalidades da mulher popular (Porto Alegre 1889 - 1900). 2018. Dissertação (Mestrado em História) - Universidade do Vale do Rio dos Sinos, São Leopoldo, 2018.
} 
Outros Tempos, vol. 18, n. 31, 2021, p. 59-86. ISSN: 1808-8031

galego tenha dito que os seus progenitores eram portugueses. Pelo visto, as autoridades tinham alguma informação de que o réu havia morado na fronteira com o Uruguai, na cidade de Jaguarão, e que saíra dali por problemas com a polícia, mas Bento Manoel renegou a suspeita, dizendo que de lá se mudara "pois ali não corria o negócio"40.

Voltando ao inventário post-mortem de 1874, o monte-mor, a soma da avaliação do patrimônio do casal Bento e Silvana, era de 12:157\$462 réis, sendo cerca de 54\% concentrado nos bens de raiz abaixo:

Tabela 1: Bens de raiz do casal Bento Manoel Veloso \& Silvana Maria do Rosário

\begin{tabular}{|l|c|}
\hline $\begin{array}{l}\text { Ilha dos Carás Pequenos, fronteira a esta cidade, com casa de moradia e } \\
\text { benfeitorias; }\end{array}$ & $3: 000 \$$ \\
\hline $\begin{array}{l}\text { Ilha do Quilombo, fronteira a esta cidade, com casas em mau estado e mais } \\
\text { benfeitorias; }\end{array}$ & $1: 500 \$$ \\
\hline $\begin{array}{l}\text { Terreno com casa nos subúrbios da cidade, na estrada denominada } \\
\text { antigamente do Ilhéu, hoje da Floresta, com 10 palmos de frente e 30 de } \\
\text { fundos (casa na rua de São Pedro, desta cidade, fazendo frente para a rua da } \\
\text { Floresta); }\end{array}$ & \\
\hline $\begin{array}{l}\text { Um terreno na antiga rua do Arvoredo, hoje Fernando Machado, com } 22 \\
\text { palmos de frente ao sul; }\end{array}$ & $400 \$$ \\
\hline $\begin{array}{l}\text { Quinhão nos matos (pedaço de campo e matos) denominados Oveiro, no } \\
\text { distrito sul de Viamão, comprado a Clemente Manoel dos Santos; }\end{array}$ & $200 \$$ \\
\hline
\end{tabular}

Fonte: APERS - Juizado de Órfãos de Porto Alegre, inventário $n^{\circ}$ 474, inventariado: Bento Manoel Velloso, inventariante: Silvana Maria Veloso, ano: 1874.

O transporte da produção desta unidade rural era garantido por uma carroça ( $30 \$$ réis) e três canoas: uma grande de quatro remos de voga (150\$), uma mais pequena com quatro remos de voga $(100 \$)$ e uma pequeninha de remo de pá (20\$). Não sabemos qual dessas embarcações transportou o cadáver do escravizado Adão, navegando pelo rio Jacuí até o rio dos Sinos, à meia-noite, numa procissão fluvial macabra. O rebanho arrolado era ínfimo, composto de 3 vacas com crias (100\$) e um novilho (32\$). No rol de bens existia ainda um debulhador de milho (30\$), mostrando que o forte daquela propriedade era a agricultura, produzindo também farinha e carvão (além de lenha) para o abastecimento da população da capital da província.

O galego assassinado teve outras inserções econômicas em Porto Alegre. Em 1854, ele aparece sendo notificado, junto com outros vendeiros, pelo Procurador da Câmara Municipal da capital Antônio Augusto Guimarães, para pagar uma multa de 20 mil réis, “em

\footnotetext{
${ }^{40}$ APERS - Juízo Municipal de Porto Alegre, Processo judicial - n⿳ 3630, réu: Bento Manoel Veloso, autor: João do Carmo, 1851.
} 
Outros Tempos, vol. 18, n. 31, 2021, p. 59-86. ISSN: 1808-8031

que incorreram pela transgressão da Postura Municipal que proíbe conservarem-se abertas nos limites da Cidade, aquelas casas de negócio nos domingos e dias santos de guarda". Segundo o fiscal da Câmara, Bento Manoel Veloso tinha uma venda na rua da Praia nº 296, tendo gente dentro do estabelecimento fora de horas e vendendo a outros que estavam na rua pela janela que tinha, aberta para a Rua do Rosário. Dois anos depois, em 1856, Bento Manoel Veloso \& Companhia tinham uma taberna na rua de Bragança, $n^{\circ} 7$ (atual Marechal Floriano), no centro da capital, quando foi multado em 6 mil réis pelo mesmo Procurador, por ter contrariado o artigo 27 das posturas municipais, "conservando carne seca pendurada fora do portal de sua taberna" 41 .

Talvez venha da época em que gerenciava essa venda no Beco do Rosário, a proximidade de Bento Manoel com a igreja que ali funcionava, frequentada majoritariamente por afro-católicos. Quiçá nessa época conheceu Silvana Maria do Rosário, devota da Imaculada, que pode tê-lo introduzido a essa devoção. Não duvidamos que seus escravizados, incluindo o homicida devoto, frequentassem as cerimônias daquele templo santo.

O inventário post-mortem organizado pela viúva de Bento Manoel nos apresenta outros parceiros de cativeiro daquele afro-católico homicida. Não sabemos onde aqueles escravizados moravam, pois se existia uma senzala na propriedade, deve ter sido avaliada junto com as benfeitorias. Talvez por serem poucos, apenas dois, os cativos morassem na casa senhorial, em algum compartimento ao lado da cozinha ou nela mesmo. Avaliada por 700 mil réis temos a preta Caetana, de aproximadamente 30 anos de idade, filiação desconhecida, solteira, com aptidão para todo o trabalho, mas especializada no serviço doméstico. Além de Caetana, sustentava aquela família de pequenos senhores escravistas com seu trabalho, o também preto Antônio, muito velho, com 60 anos mais ou menos, avaliado por 150 mil réis.

Vários pesquisadores já alertaram para as potencialidades, mas também para os riscos do uso dos inventários post-mortem como fonte histórica. Os usos quantitativos e qualitativos dessa fonte são enormes, mas temos sempre que ter em mente que os inventários post-mortem congelam uma trajetória genealógica e patrimonial, gerando uma visão momentânea das vivências daquele indivíduo e do seu núcleo familiar ${ }^{42}$. É provável, por

\footnotetext{
${ }^{41}$ APERS - Juízo Municipal de Porto Alegre, Notificação para imposição de multa, nº 6086, Notificado: Bento Manoel Velloso (e outros), Notificante: Câmara Municipal de Porto Alegre, 1854; APERS - Delegacia de Polícia de Porto Alegre, Notificação para Imposição de Multa, no 3167, suplicante: Capitão Antônio Augusto Guimarães (Procurador da Câmara Municipal de POA), suplicado: Bento Manoel Velloso e Companhia, 1856. ${ }^{42}$ FURTADO, Junia. A morte como testemunho da vida. In: LUCA, Tânia Regina de; PINSKY, Carla Bassanezi (org). O historiador e suas fontes. São Paulo: Contexto, 2009; FARINATTI, Luís Augusto. Construção de séries e micro-análise: notas sobre o tratamento de fontes para a história social. Anos 90, Porto Alegre, UFRGS, v. 15, n. 28, p. 57-72, jul. 2008; FRAGOSO, J.; PITZER, R. R. Barões, homens livres pobres e escravos: notas sobre fonte múltipla - inventários postmortem. Revista Arrabaldes, Petrópolis, n. 2, p. 29-52, set./dez. 1998;
} 
Outros Tempos, vol. 18, n. 31, 2021, p. 59-86. ISSN: 1808-8031

exemplo, que junto da crioula Caetana estivesse a sua filha ingênua Justina, de menos de dois anos, descrita no seu batismo ocorrido em 24 de novembro de1872 como parda, tendo nascido em 9 de outubro daquele mesmo ano. No ano seguinte nasceriam os gêmeos João e Maria, em 30 de março de 1875, do mesmo ventre escravizado, batizados em 6 de junho seguinte $e^{43}$.

Segundo o clássico trabalho de Kátia de Queiros Mattoso ${ }^{44}$, os ingênuos, categoria criada a partir da lei do ventre livre de 1871, não tinham mais o valor-mercadoria dos escravizados, mas ainda assim continuavam valiosos para os seus senhores, que usufruíam o seu valor-trabalho. Melina Perussatto, analisando os inventários post-mortem da cidade de Rio Pardo (RS) no pós-1871, encontrou os ingênuos avaliados segundo os anos e a qualidade dos serviços que ainda podiam e tinham que prestar aos senhores até os 21 anos de idade ${ }^{45}$. $\mathrm{O}$ fato da menina Justina não aparecer no inventário de 1874, talvez signifique que ela ainda era muito pequenina e seus serviços não eram considerados validos, ou então, como não tinha ainda chegado aos 8 anos de idade, considerava-se que ela estava sob a alçada temporária da mãe, até por ser essa etapa etária muito vulnerável à elevada mortalidade infantil do período ${ }^{46}$.

Talvez no período em que teve uma venda na rua da Praia, Bento Manoel Veloso tenha conseguido acumular alguns recursos. Nesse período é que localizamos o primeiro batizado de um escravizado seu. Em 16 de julho de 1855, na Igreja do Rosário, vizinha a sua venda, foi batizado Cipriano, nascido em 20 de fevereiro daquele ano, filho da escravizada

FRAGOSO, João. Alegrias e artimanhas de uma fonte seriada. In: FRAGOSO, João. História quantitativa e serial no Brasil: um balanço. Goiânia: ANPUH-MG, 2001. Não é a toa, assim, que alguns autores recomendam que também se faça a análise das escravarias (estrutura de possa escrava) pelos batismos. MATHEUS, Marcelo Santos. A produção da diferença: escravidão e desigualdade social ao sul do Império brasileiro (Bagé, c.18201870). 2016. Tese (Doutorado em história) - Universidade Federal do Rio de Janeiro, Rio de Janeiro, 2016. p. 188.

${ }^{43}$ AHCMPA - Livro de Batismos de Ingênuos da Paróquia de Nossa Senhora do Rosário, folha 16; Livro de Batismos de ingênuos da Igreja Matriz da Madre de Deus, folha 12.

${ }^{44}$ MATTOSO, Kátia de Queiros. Ser escravo no Brasil. São Paulo: Brasiliense, 1982.

${ }^{45}$ PERUSSATTO, Melina Kleinert. Como se de ventre livre nascesse: experiências de cativeiro, parentesco, emancipação e liberdade nos derradeiros anos da escravidão - Rio Pardo/RS, c.1860 - c.1888. 2010. Dissertação (Mestrado em História) - Universidade do Vale do Rio dos Sinos, São Leopoldo, 2010.

${ }^{46}$ Sobre a infância e os ingênuos, ver: ALANIZ, Anna Gicelle García. Ingênuos e libertos: estratégias de sobrevivência familiar em épocas de transição (1871-1895). Campinas: CMU/UNICAMP, 1997; GEREMIAS, Patrícia Ramos. Ser "ingênuo" em Desterro/SC: a lei de 1871, o vínculo tutelar e a luta pela manutenção dos laços familiares das populações de origem africana (1871-1889). Niterói, RJ: PPGH, UFF, 2005; PAPALI, Maria Aparecida C. R. Escravos, libertos e órfãos: a construção da liberdade em Taubaté (1871-1895). São Paulo: Annablume, FAPESP, 2003; TEIXEIRA, Heloísa Maria. A não-infância: crianças como mão de obra em Mariana (1850-1900). 2007. Doutorado (Tese em História) - Universidade de São Paulo, São Paulo, 2007; ZERO, Arethuza Helena. O preço da liberdade: caminhos da infância tutelada - Rio Claro (1871-1888). 2004. Dissertação (Mestrado em História)- Universidade Estadual de Campinas, Campinas, SP, 2004. 
Outros Tempos, vol. 18, n. 31, 2021, p. 59-86. ISSN: 1808-8031

Maria $^{47}$. Infelizmente, o preto Cipriano faleceu em 3 de agosto, ainda no seu primeiro ano de vida, de angina. Além do óbito do menino Cipriano, temos:

Tabela 2: Óbitos de Escravizados de Bento Manoel Veloso

\begin{tabular}{|l|l|l|l|l|l|}
\hline \multicolumn{1}{|c|}{ Data } & \multicolumn{1}{c|}{ Nome } & \multicolumn{1}{c|}{ Cor } & \multicolumn{1}{c|}{ Idade } & \multicolumn{1}{c|}{ Origem } & \multicolumn{1}{c|}{ Causa morte } \\
\hline 17.12 .1864 & Felizardo & Preta & 45 anos & África & SAM $^{48}$ \\
\hline 29.10 .1867 & Joaquim & Preta & 60 anos & Bahia & Consumpção \\
\hline 09.09 .1868 & Manoel & Preta & REN $^{49}$ & POA & Tétano \\
\hline 07.04 .1874 & Lino & Preta & 38 anos & RS & Congestão cerebral \\
\hline
\end{tabular}

Fonte: CENTRO HISTÓRICO-CULTURAL DA SANTA CASA. Africanos na Santa Casa de Porto Alegre: óbitos dos escravos sepultados no cemitério da Santa Casa (1850-1885). Porto Alegre: EST, 2007.

Quer dizer que, somando todos os escravizados acima, com os que já foram citados neste artigo, encontramos 16 cativos presos a família Veloso, contando com os três ingênuos filhos da crioula Caetana, o assassino afro-católico José e os quatro indivíduos mortos pelo senhor assassinado (Belizário, Adão, Domingo e Vicente). Claro que dois deles, Manoel e Cipriano, viveram muito pouco, mas certamente outros existiram e não conseguimos captar os seus nomes, mas isso nos dá uma dimensão de que aquela família Veloso estava plenamente inserida naquela sociedade escravista e que geria suas unidades produtivas contando com uma escravaria, que pode ser descrita entre o pequeno e o médio porte.

Encontramos duas cartas de alforria passadas pela família Veloso. Em 2 de janeiro de 1865 (registrada em cartório no dia seguinte), Bento Manuel Veloso redigiu uma carta de liberdade para a crioula Camila, de 18 anos de idade, concedida mediante o pagamento de 1:500\$ réis pela preta africana Feliciana, mãe da escravizada. Já o africano de nação Antônio, descrito como muito velho pelos avaliadores do inventário de 1874, que o orçaram em apenas 150 mil réis, foi libertado pela viúva Silvana. Ela ditou sua vontade de alforriá-lo a Antônio Gonçalves Padilha, em 21 de janeiro de 1876, e justificou-se dizendo que a carta era concedida "em retribuição aos bons serviços prestados"

Considerando o censo de 1872, e tentando através dele dar uma dimensão da distribuição demográfica de Porto Alegre no período, percebemos que a maior comunidade de estrangeiros da capital da província sulina era justamente a dos africanos, composta de 830 indivíduos livres $(51,62 \%)$ e 778 (48,38\%) escravizados. Os africanos representavam 29,92\% dos estrangeiros de Porto Alegre, os portugueses, 23,63\% e os alemães 17,41\%.

\footnotetext{
${ }^{47}$ AHCMPA - Livro $1^{\text {o }}$ de Batismos de Escravos da Igreja de Nossa Senhora do Rosário, folha 211.

${ }^{48}$ Sem assistência médica.

${ }^{49}$ Recém-nascido.

${ }^{50}$ APERS $-1^{\circ}$ Tabelionato de Porto Alegre, Registros Diversos livro 23, folha 139.
} 
Outros Tempos, vol. 18, n. 31, 2021, p. 59-86. ISSN: 1808-8031

Os africanos, em função das características já conhecidas do tráfico transatlântico, tinham um desnivelado padrão demográfico em termos da distribuição sexual ${ }^{51}$. Os homens representavam $989(61,5 \%)$ do total de africanos residentes em Porto Alegre em 1872, enquanto as mulheres eram 619 (38,5\%). Seja pelas dificuldades desse mercado matrimonial (que não impedia o casamento/amasiamento entre africanos e crioulos) ou pela opção étnica em não se casar na Igreja, temos apenas 204 (12,69\%) desses indivíduos (certamente adultos em função do fim do tráfico internacional em 1850) envolvidos em relações afetivo-familiares oficiais e 1.404 solteiros $(87,31 \%)^{52}$.

A capital da província - Porto Alegre - tinha, ainda segundo o censo de 1872, uma população total de 43.998 habitantes, sendo $81,46 \%$ livres/libertos e $18,54 \%$ escravizados. Ou seja, os libertos não foram descriminados separadamente e constavam somados na categoria de livres. O equilíbrio demográfico entre os sexos, produto do processo resultante da reprodução natural, era evidente. Se entre os livres os percentuais eram de $51,24 \%$ de homens e 48,76\% de mulheres, os escravizados dividiam-se entre um segmento masculino de $50,72 \%$ e feminino de $49,28 \%$. Quanto as representações sociais das cores (raças) da população, segundo os responsáveis pelo censo, temos:

Tabela 3: População de Porto Alegre / censo de 1872 - condição, sexo, cor.

\begin{tabular}{|l|r|r|r|r|r|r|r|}
\hline Raças & \multicolumn{3}{|c|}{ Livres } & \multicolumn{3}{c|}{ Escravos } & \\
\hline & Homens & Mulheres & \multicolumn{1}{c|}{ Soma } & Homens & Mulheres & Soma & \multicolumn{1}{c|}{ Total } \\
\hline Branca & 12.052 & 10.881 & 22.933 & 0 & 0 & 0 & 22.933 \\
\hline Parda & 2.998 & 3.048 & 6.046 & 1.435 & 1.522 & 2.957 & 9.003 \\
\hline Preta & 2.357 & 2.407 & 4.764 & 2.701 & 2.497 & 5.198 & 9.962 \\
\hline Cabocla & 958 & 1.142 & 2.100 & 0 & 0 & 0 & 2.100 \\
\hline Total & 18.365 & 17.478 & 35.843 & 4.136 & 4.019 & 8.155 & 43.998 \\
\hline
\end{tabular}

Fonte: http://biblioteca.ibge.gov.br/visualizacao/livros/liv25477_v11_rs.pdf

Somando os pardos e os pretos livres da tabela acima, temos 10.810 indivíduos, que somados aos 8.155 habitantes negros ainda escravizados, contabilizam 18.965 pessoas, ou seja, aproximadamente 57\% da população negra de Porto Alegre, em 1872, já era livre ou forra, isso 16 anos antes da abolição definitiva. Quer dizer, mais de $43 \%$ da população da capital do RS era negra, incluindo os ainda escravizados, os livres e libertos. Sabemos como a

\footnotetext{
${ }^{51}$ Sobre o tráfico, ver: FLORENTINO, Manolo. Em costas negras: uma história do tráfico de escravos entre a África e o Rio de Janeiro. São Paulo: Companhia das Letras, 1997; BERUTE, Gabriel Santos. Dos escravos que partem para os portos do sul: características do tráfico negreiro do Rio Grande de São Pedro do Sul, c. 1790- c. 1825. 2006. Dissertação (Mestrado em História)- Universidade Federal do Rio Grande do Sul, Porto Alegre, 2006.

${ }^{52}$ Disponível em: http://biblioteca.ibge.gov.br/visualizacao/livros/liv25477_v11_rs.pdf.
} 
Outros Tempos, vol. 18, n. 31, 2021, p. 59-86. ISSN: 1808-8031

liberdade branqueava os indivíduos, invisibilizando as origens africanas de muitas genealogias, portanto, certamente muitos livres brancos eram apenas socialmente brancos, possuindo origens familiares marcadas pela diáspora transatlântica. Se cometermos o abuso demográfico de somar ainda os caboclos, teríamos 47,88\% da população da capital incluída numa ampla categoria de não-brancos. Considerando a população de toda a província sob a perspectiva desse mesmo tipo de cálculo especulativo, o número seria de 176.446 indivíduos não brancos, sendo 71.259 pardos, 79.477 pretos e 25.710 caboclos, ou seja, $40,58 \%$ da população total. Ou seja, existia uma audiência ampla (de brancos e não-brancos) aguardando os desdobramentos daquele julgamento.

Algumas pesquisas confirmam a forte presença africana na capital da província sulina. Analisando as alforrias cartoriais na segunda metade do século XIX, pesquisas verificaram que, entre aqueles documentos de liberdade nos quais foi possível captar a origem dos alforriados, temos 952 africanos e 1.276 crioulos. Dos 952 africanos, 362 eram acompanhados de denominações de origem genéricas, como da África (116), da Costa da África (11) ou de nação (235). O restante pode nos ajudar a entender a procedência dos africanos escravizados, contemporâneos do crime da Ilha do Quilombo. Da África Ocidental vieram 432 dos alforriados, da África Oriental 35 e da África Central Atlântica, 123. Os mais eficientes em termos de obtenção de alforrias foram, sem dúvida, os africanos ocidentais, principalmente os minas (157) e nagôs (257). Quando nos referimos a eficiência, não estamos apenas nos expressando levianamente, mas considerando que 59\% desses africanos compraram as suas liberdades ${ }^{53}$.

Concordamos com algumas considerações do historiador James Sweet, quando ele afirma que mesmo que estejamos conscientes da "enorme diversidade linguística e cultural nas populações escravas da diáspora africana", não consideramos "estas diferenças como barreiras ou obstáculos à reinvenção de formas culturais africanas". Evidentemente, considerar as autorepresentações das populações afro-diaspóricas exige uma mescla de procedimentos metodológicos quantitativos e qualitativos, já que "os 'números' dizem-nos pouco sobre a forma como os africanos entendiam a etnicidade". Neste caso, indícios

\footnotetext{
${ }^{53}$ Ver: MOREIRA, Paulo Staudt; TASSONI, Que com seu trabalho nos sustenta: as cartas de alforria de Porto Alegre (1748 / 1888). Porto Alegre: EST, 2007; MOREIRA, Paulo Staudt. Os cativos e os homens de bem: experiências negras no espaço urbano. Porto Alegre: Edições EST, 2003. (principalmente o capítulo 3). Sobre a questão da africanidade em um período anterior, na mesma localidade, ver: MOREIRA, Paulo Roberto Staudt. Escravidão, família e compadrio: a comunidade escrava no processo de ilegalidade do tráfico internacional de escravos (1831-1850). Revista História Unisinos, v. 18, n. 2, p. 312-337, maio/ago. 2014.
} 
Outros Tempos, vol. 18, n. 31, 2021, p. 59-86. ISSN: 1808-8031

captados em documentos judiciários, podem nos ajudar a entender as complexas perspectivas identitárias diaspóricas ${ }^{54}$.

\section{O julgamento}

No meio desse processo de recolhimento de provas testemunhais e materiais e de autoridades e vizinhos emitindo opiniões sobre o ocorrido, um ofício da viúva Silvana Maria Veloso deve ter desassossegado ainda mais os ânimos. Em 4 de maio daquele trágico ano de 1874, Silvana informava para as autoridades que havia exercido o seu poder senhorial outorgando uma carta de liberdade ao preto José, réu pelo assassinato de seu marido, em 30 de março daquele mesmo ano. Apesar da declaração da viúva Silvana, o documento registrado em cartório em 4 de maio de 1874, que alforriava o africano de nação José, então com 50 anos de idade, trazia a data de redação de 30 de abril de 1874. O documento de liberdade, ditado pela analfabeta Silvana Maria Veloso a Antônio Félix de Bitencourt, era absolutamente sintético e apenas concedia plena liberdade, sem qualquer justificativa ${ }^{55}$. Se o documento fosse de 30 de março, José seria já forro quando cometeu o crime e, portanto, não poderia ser incurso na lei de 1835. Difícil compreender as motivações daquela recente viúva, se ela queria simplesmente distanciar aquele preto assassino de seu convívio, ao mesmo tempo que se desonerava dos custos com o seu julgamento, ou se procurara beneficiá-lo com a liberdade.

Silvana Maria Veloso enterrou o marido em 1874 e casou novamente dois anos depois, talvez com um parente de seu primeiro marido, chamado José Manoel Veloso, na Capela do Menino Deus ${ }^{56}$. Ela nasceu na província do Rio Grande do Sul, mas esse seu segundo marido era português, nascido na freguesia de Travassos, Conselho de Vila Verde, Bispado de Braga, filho legítimo de Matias Veloso e Custódia Maria. Ele saiu de Portugal em 1867 e foi para a província do Pará, com então 43 anos de idade; de lá, em 1869, foi para Montevidéu, lá permanecendo até 1871, quando veio para esta província (ficou dois anos em Pelotas e depois veio para Porto Alegre). Os noivos eram moradores na freguesia do Rosário, em Porto Alegre, e Silvana apresentou o registro de óbito de seu marido, branco, casado, natural de Portugal (mostrando que ela mesma tinha problemas para definir a nacionalidade daquele galego), causado por "ferimento de arma branca", morto com 50 anos de idade. Percebemos em alguns outros casos, a possibilidade de que alguns casamentos realizados na

\footnotetext{
54 SWEET, James H. Recriar a África: cultura, parentesco e religião no mundo afro-português (1441-1770). Lisboa: Edições 70, 2007, p. 31 e 35. (Lugar da História, 69).

${ }^{55}$ APERS $-2^{\circ}$ Tabelionato de Porto Alegre, Registros Gerais livro 20, folha 27v.

${ }^{56}$ AHCMPA - 1876, 223. Habilitação matrimonial. Noivo: José Manoel Veloso e Silvana Maria Veloso.
} 
Outros Tempos, vol. 18, n. 31, 2021, p. 59-86. ISSN: 1808-8031

Capela do Menino Deus, localizada longe do centro da capital da província, ocorressem ali por quererem os noivos alguma privacidade. Talvez tendo enviuvado recentemente e realizando segundas núpcias com um suposto parente do marido falecido, a viúva procurasse certa distância dos olhares indiscretos e moralistas de seus vizinhos. Será que o fato de ter alforriado o cativo responsável pela morte de seu marido causara algum constrangimento junto a vizinhança? Na habilitação ela é chamada de viúva e trata Bento de seu finado marido.

Com a alforria passada, a viúva livrava-se de ter que arranjar e pagar defensor ao cativo homicida de seu marido, mas também causava embaraços a justiça de julgá-lo pela lei excepcional de 1835. Mesmo assim, o Promotor Público, em junho daquele ano, declarou que considerava evidente a criminalidade do africano José e pedia que ele fosse incurso no artigo $1^{\circ}$ da lei de 10.06.1835, “já que era escravo na época”. O Juiz de Direito do $1^{\circ}$ distrito criminal Trajano Viriato de Medeiros, presidiu a sessão do júri de 18 de setembro de 1874, na qual o assassinato do galego Veloso foi julgado.

Os juízes de fato, os jurados, ficaram isolados em uma sala a portas fechadas (como determinava o artigo 270, do Código de Processo Penal de 1832) e na saída apresentaram ao juiz as respostas que deram aos quesitos por ele fornecidos. Os 14 jurados dividiram-se quanto ao primeiro quesito, que indagava se José havia matado seu senhor Bento José Veloso, com apenas sete deles dizendo efetivamente - sim. A mesma desarmonia marcou a resposta ao segundo quesito: quando cometeu o assassinato, o réu era ainda escravizado? Sete jurados disseram que não. Um relativo consenso somente emergiu na resposta ao $3^{\circ}$ quesito, que indagava se o réu havia cometido o crime violentado por medo irresistível, quando 11 jurados responderam afirmativamente. Com aqueles posicionamentos dos jurados, o juiz teve que absolver o africano José, que saiu do tribunal inocentado e ainda forro.

Merece aqui menção a pesquisa de Ricardo Pirola sobre a Lei Excepcional de 1835, que tornou sumário o rito judiciário que punia os escravizados que matavam seus senhores. No prefácio escrito para o livro de Pirola - prêmio do Arquivo Nacional -, o historiador Robert Slenes informa que: "Na sua origem, a lei era descaradamente uma arma senhorial contra a senzala insurgente. Nas últimas décadas da escravidão, no entanto, suas bases progressivamente minadas por diversos protagonistas históricos desde conselheiros de Estado até os próprios cativos, ela foi se transformando em ameaça a casa-grande". Pirola menciona que, em 1879, o Clube da Lavoura de Campinas protocolou na Câmara dos Deputados um pedido para que a lei fosse extinta. Segundo esse autor, ao longo da segunda metade do oitocentos a lei de 1835 foi sendo subvertida, com a jurisprudência cada vez mais atenuando os seus efeitos com o diálogo com os códigos Criminal (1830) e Processual (1832). 
Outros Tempos, vol. 18, n. 31, 2021, p. 59-86. ISSN: 1808-8031

Além disso, os pedidos de graça ao Imperador também subverteram o princípio da lei, fazendo com que muitos escravos homicidas acabassem sendo perdoados e libertos:

Assim, é possível que, a partir dessa época, a opção de tentar resolver um determinado conflito diretamente com o senhor ou por intermédio de um padrinho tenha se tornado menos interessante aos cativos do que recorrer aos agentes do Estado. O resultado, ao que parece, foi a formação de um ciclo em que os senhores, sentindo-se pouco prestigiados pelo Império e desrespeitados por seus escravos, passaram a querer solucionar eventuais conflitos por conta própria e de maneira cada vez mais severa, levando mais e mais cativos a recorrerem aos agentes públicos do Império $^{57}$.

\section{Considerações finais}

Mas aceitando a provocação do talentoso e criativo romancista que citamos na epígrafe deste artigo, em que consiste, exatamente, um crime? Registrar um ato como criminoso, investigando-o e apontando réus e vítimas, significa que ele contraria algum ponto de um código de normas jurídicas. Mas os documentos judiciários, como bem sabem os cientistas sociais que os tem frequentemente acessado nos últimos anos, são polifônicos, eles não expressam apenas uma unívoca impressão sobre o ocorrido, mas uma combinação simultânea de várias vozes, que nos indicam consensos e dissensos sociais diversos, decorrentes das distintas posições econômicas, profissionais, étnico-raciais e mesmo de gênero dos informantes, que ali registravam de alguma forma suas opiniões a respeito do ocorrido. Assim, os momentos criminosos, que chegam até nós pela pena das autoridades policiais e judiciárias, que compilam falas diversas, nos ajudam a entender as perspectivas dos escravizados, no diálogo com os ethos e habitus senhoriais. Segundo Mariana Muaze:

[...] no que compete às relações entre senhores e escravos no âmbito doméstico, muito ainda há para ser estudado. Afinal, as relações escravistas exercidas na esfera privada se, por um lado, envolviam afetividades, dedicação e fidelidades entre os sujeitos históricos em questão, por outro, eram gestadas num ambiente de abuso, humilhação, violência física e simbólica, característico da própria escravidão como instituição. O que a princípio pode ser lido como paradoxo, ambiguidade, era na verdade constitutivo da ideologia de dominação vivenciada, por senhores e escravos, de formas diferentes, no interior das casas-grandes e sobrados. Mais do que isso, a figura da ama de leite e a prática social da amamentação por escravas negras, largamente disseminada no seio da classe dominante, auxiliaram na configuração de um habitus senhorial, uma segunda natureza, na qual os futuros senhores, desde a

\footnotetext{
${ }^{57}$ PIROLA, Ricardo. Escravos e rebeldes nos Tribunais do Império: uma história social da lei de 10 de Junho de 1835. Rio de Janeiro: Arquivo Nacional, 2013. p. 6, 224.
} 
Outros Tempos, vol. 18, n. 31, 2021, p. 59-86. ISSN: 1808-8031

mais tenra idade, experimentavam relações escravistas no seu cotidiano e intimidade ${ }^{58}$.

Mesmo que a pesquisadora acima esteja interessada especialmente nas amas de leite e demais trabalhadoras domésticas, numa análise interseccional, serve-nos para refletir sobre a questão do paternalismo e das mentalidades senhoriais, em confronto com as expectativas de trabalhadores e trabalhadoras negras, ainda escravizadas e mesmo forras ${ }^{59}$.

Se o africano José era realmente, como disseram algumas testemunhas, um fiel servidor do falecido senhor e se a sua postura na sexta-feira santa foi coerente com a sua crença afro-católica, como isso se coaduna com a postura de sua senhora Silvana Maria do Rosário? Alforriá-lo significaria que ela achou compreensível o seu impulso homicida? Seria uma crítica ao modo irresponsável e brutal como seu falecido marido tratava os trabalhadores escravizados de sua casa? Será uma espécie de vingança, demonstrando compreensão por ela também ter sido vítima dos abusos do defunto marido ou amásio? Levantar questões, mesmo que irrespondíveis integralmente, é por si só indicativo de potenciais respostas, nesse caso cruzando políticas senhoriais, gênero e mesmo sensibilidades religiosas e étnico-raciais (lembrando que advogamos que a senhora Silvana tinha ascendência africana).

A referência de José, de ser natural da Costa da África, não nos diz muito especificamente de onde ele provinha e de qual africanidade ele era portador. O nome do pai Agebé - o qual não sabemos se era exatamente assim ou se dessa forma foi ouvido pelos interrogadores -, e a fé católica expressada por José, nos inclina a cogitar que fosse originário da cultura banto, da região Congo-Angola. ${ }^{60} \mathrm{O}$ título fantasia deste artigo remete ao depoimento dado por aquele roceiro e lavrador da Costa da África, que por volta dos seus 50 ou 60 anos de idade (dependendo da fonte), esfaqueou e matou o seu senhor, na então Ilha do Quilombo, fronteira a Porto Alegre. Recebendo o imposto batismo católico e sendo

\footnotetext{
${ }^{58}$ MUAZE, Mariana. Maternidade silenciada: amas de leite no Brasil escravista, século XIX. In: OSÓRIO, Helen; XAVIER, Regina. Do tráfico ao pós-abolição: trabalho compulsório e livre e a luta por direitos sociais no Brasil. São Leopoldo: Oikos, 2018. p. 360- 391. p. 361.

${ }^{59}$ Ricardo Salles usa a expressão "ethos senhorial-escravista", enquanto Marcelo Matheus, constando que parte significativa das escravarias era formada de escravizados ligados ao trabalho doméstico, fala da existência de uma cultura escravista: "Portanto, ser senhor de outros homens era algo que ia para além da questão econômica e/ou produtiva, tornando a compreensão daquela cultura escravista (isto é, uma mentalidade em que a busca por tornar-se senhor era algo que atravessava todos os estratos sociais) mais complexa". SALLES, Ricardo. E o vale era escravo: vassouras, século XIX. Senhores e escravos no coração do Império. Rio de Janeiro: Civilização Brasileira, 2008. p. 32; MATHEUS, Marcelo Santos. A produção da diferença: escravidão e desigualdade social ao sul do Império brasileiro (Bagé, c.1820-1870). 2016. Tese (Doutorado em história) - Universidade Federal do Rio de Janeiro, Rio de Janeiro, 2016. p. 184.

${ }^{60}$ Robert Slenes. Malungu, ngoma vem! África coberta e descoberta do Brasil. Revista USP, n. 12, (1991/92); SOUZA, Marina de Mello e. Reis negros no Brasil escravista: história de coroação de Rei Congo. Belo Horizonte: Editora UFMG, 2002; Marisa de Carvalho Soares. Devotos da cor: identidade étnica, religiosidade e escravidão no Rio de Janeiro, século XVIII. Rio de Janeiro: Civilização Brasileira, 2000;
} 
Outros Tempos, vol. 18, n. 31, 2021, p. 59-86. ISSN: 1808-8031

(re)nomeado como José, tornando-se justamente homônimo do pai de Jesus Cristo, aquele homicida justificou seus sanguinolentos atos (lembremos que foram dadas três eficientes facadas) contando aos seus algozes: "Que o assassinado não tinha religião, nem contava com Deus Pai, que na sexta-feira santa, querendo ele respondente guardar o jejum, foi por esse motivo atrozmente espancado pelo dito seu senhor, tendo então perdido a paciência e assassinou-o nesse ato".

Sabemos do peso nos interrogatórios dos próprios interrogadores, mas a primeira frase, que justamente dá título a esse artigo, apostamos ter sido pronunciada pelo réu, e que o escrivão, como uma espécie de "antropólogo", verteu no papel, seduzido talvez pela beleza e aparente sinceridade daquela expressão. Quem sabe houve naquele momento uma singular empatia entre aqueles agentes do controle social e o réu africano, num diálogo cultural mediado pelo filtro religioso.

Paul Gilroy, teorizando sobre o Atlântico Negro, explica que os navios são um sistema vivo, microcultural e micropolítico em movimento: "Deve-se enfatizar que os navios eram os meios vivos pelos quais se uniam os pontos naquele mundo atlântico. Eles eram elementos móveis que representavam os espaços de mudança entre os lugares fixos que eles conectavam". Segundo Gilroy, esses barcos transatlânticos, incluídos aí os navios negreiros, “precisam ser pensados como unidades culturais e políticas em lugar de incorporações abstratas do comércio triangular" ${ }^{\prime 61}$. Talvez a frase pronunciada pelo africano José fizesse parte de uma retórica usada por ele como argumento de defesa naquele tribunal dos brancos, mas também não excluímos uma honesta e multifacetada devoção religiosa. Cláudia Rodrigues, usando como fontes testamentos de africanos libertos, analisou a relação entre catolicismo e africanidade no estudo da religiosidade negra na América portuguesa. Essa pesquisadora, baseada em John Thornton, analisa a formação das culturas afro-americanas, nas quais o complexo campo religioso concorreu enormemente nos heterogêneos resultados encontrados. Para esse autor, segundo Rodrigues:

[...] a cultura afro-americana tornou-se muito mais homogênea do que as diversas culturas africanas que a compuseram, fundindo-as e incorporando a cultura europeia [...] Exemplo disso pode ser visto no aspecto da religiosidade. Para ele, o resultado a nova religião afro-atlântica que se originou identificou-se com a cristã, mas se constituiu em um tipo de cristianismo que satisfazia o entendimento das religiões africanas e europeia. Para Thornton, esse cristianismo africano permitiu que a filosofia e o conhecimento de algumas religiões africanas se acomodassem em um sistema religioso europeu e expressassem uma fusão de grande importância,

\footnotetext{
${ }^{61}$ GILROY, Paul. O Atlântico negro: modernidade e dupla consciência. São Paulo: Ed. 34, 2001. p. 60.
} 
Outros Tempos, vol. 18, n. 31, 2021, p. 59-86. ISSN: 1808-8031

tornando-se algo mais do que a simples mistura de formas e ideias de uma religião com outra ${ }^{62}$.

Mas quando falamos de sensibilidades e identidades afro-diaspóricas, não estamos tratando de questões nascidas apenas a partir do tráfico transatlântico, pois processos gerados em criativa hibridez já estavam em andamento no próprio continente africano. Esse é o caso da questão que estamos insistindo desde o início, do afro-catolicismo do africano José. Lucilene Reginaldo é uma das historiadoras que tem percebido o diálogo fértil entre as crenças africanas e europeias, investindo no estudo das irmandades negras, percebendo nessas associações religiosas leigas vestígios de "um catolicismo africanizado"63.

Em seu último livro, Além do Visível, Marina de Mello e Souza volta a discutir o catolicismo africano na região do Congo, percebendo como "símbolos e ritos estrangeiros foram incorporados a partir das cosmogonias autóctones”. Souza dialoga com autores como John Thornton, Anne Hilton e Wyatt MacGaffey, destacando que "a maneira como os centroafricanos, especialmente aqueles que ocupavam posições de mando, construíram suas relações com os portugueses orientou-se pelos seus sistemas cognitivos, ou seja, pela maneira como entendiam o mundo, a natureza, as sociedades e todos os fenômenos da vida humana”. Nessa cosmogonia bakongo o desenho da cruz, por exemplo, significaria o ciclo básico da vida:

[...] pensando a partir dos 4 pontos percorridos pelo sol no seu movimento circular e contínuo: o nascimento, quando desponta no horizonte; a maturidade, quando alcança o ponto mais alto no céu; a morte, quando se põe do outro lado do horizonte; e a existência no mundo dos mortos quando está no polo oposto, iluminando o mundo invisível, do qual segue seu trajeto circular para começar novo ciclo ${ }^{64}$.

Em sua tese defendida em 2003, na Unicamp (sob a orientação da professora Silvia Lara), e publicada em 2010, a historiadora Elciene Azevedo destacou a formação de uma opinião pública ao longo da segunda metade do século XIX, no Brasil, se não

\footnotetext{
${ }^{62}$ RODRIGUES, Claudia. Morte, catolicismo e africanidade na cidade do Rio de Janeiro setecentista. Ciencias Sociales y Religión/Ciências Sociais e Religião. Porto Alegre, ano 12, n. 12, p. 31-52, out. 2010. p. 35. Ver: THORNTON, John. A África e os africanos na formação do mundo atlântico (1400-1800). Rio de Janeiro: Elsevier, 2004. Ver: GRAHAM, Sandra. Ser mina no Rio de Janeiro do século XIX. Afro-Ásia, n. 45, 2012; SOUZA, Marina de Mello e. Catolicismo negro no Brasil: Santos e minkisi, uma reflexão sobre miscigenação cultural. Afro-Ásia, n. 28, 125-146, 2002; SWEET, James H. Recriar a África: cultura, parentesco e religião no Mundo Afro-Português (1441-1770). Lisboa: Edições 70, 2007. (Lugar da História, 69).

${ }^{63}$ REGINALDO, Lucilene. Os rosários dos angolas: irmandades negras, experiências escravas e identidades africanas na Bahia setecentista. 2005. Tese (Doutorado em História) - Unicamp, Campinas, 2005. p. 7. João José Reis, analisando as irmandades negras no tempo da escravidão, pensou as formas como esses devotos estruturavam celebrações africanas do catolicismo. REIS, João José. Identidade e diversidade étnicas nas irmandades negras no tempo da escravidão. Tempo: Revista do Departamento de História da UFF, Rio de Janeiro: RelumeDumará, v. 2, n. 3, 1997.

${ }^{64}$ SOUZA, Marina de Melo e. Além do visível: poder, catolicismo e comércio no Congo e em Angola (séculos XVI e XVII). São Paulo: Edusp, Fapesp, 2018. p. 14 e 46. Ver: THORNTON, John. On the Trail of Voodoo: African Christianity in Africa and the Americas. The Americas, v. 44, n. 3, p. 261-278, 1988.
} 
Outros Tempos, vol. 18, n. 31, 2021, p. 59-86. ISSN: 1808-8031

completamente antiescravista, mas visivelmente embaraçada da vigência daquela forma de trabalho compulsório no Império. Depois de descrever e analisar algumas histórias retiradas de documentos judiciários, Elciene Azevedo declara:

O mais importante, no entanto, é que essa e outras histórias contadas aqui deixam patente como os escravos, longe de se colocarem de forma passiva diante do direito, à espera de que homens ilustrados os arrancassem da escravidão, tiveram uma percepção muito acurada do momento em que viviam e dos paradoxos que a Justiça brasileira enfrentava em relação ao seu estatuto jurídico. [....] Compartilhavam a noção de que alguns dispositivos legais pensados para coibir a violência e manter a disciplina podiam, em algumas circunstâncias, ser revertidos e talvez melhorar suas condições de vida. $\mathrm{O}$ tribunal não era espaço de unanimidades, sobretudo em relação à execução da pena de morte, e os escravos souberam avaliar isso. Era uma aposta perigosa, mas alguns, ao que parece, escolheram tudo a viver na escravidão ${ }^{65}$.

Neste contexto descrito por Elciene Azevedo, o assassinato (mesmo dos senhores) pelos escravizados, aparecia como uma “estratégia viável”. As críticas do africano José ao seu senhor estrangeiro, descreviam-no como um mau cristão (já que desrespeitava os mais importantes rituais católicos), um péssimo senhor de escravizados (que abusava dos castigos físicos até o ponto de assassinar alguns de seus trabalhadores negros cativos), mas também um deficiente ser humano, pois não tinha honra, já que desrespeitava as recíprocas obrigações do código paternalista vigente no escravismo.

Segundo Johnson e Palmié, os "africanos escravizados entraram em estruturas institucionais que geraram oportunidades e limitações localmente especificas quando se tratava de reafirmar noções de suas relações com entidades - espíritos, divindades, ancestrais, forças da natureza - que eram parte integrante de seu mundo"66. Assim, através desse crime acontecido na Ilha do Quilombo, em 1874, podemos perceber uma espécie de idioma afrocatólico, funcionando como meio de tradução de insatisfações dos escravizados, através de um diálogo audível e compreensível com os indivíduos brancos que dominavam as esferas policiais e judiciárias. Não se trata apenas, evidentemente, de enganação, dissimulação ou de cópia, mas de entendimento da linguagem cultural ali esperada como hegemônica (principalmente no campo jurídico). O africano da costa José manifestou-se, naquele momento, ao ser interrogado, com toda a sinceridade, movido pelo mesmo sentimento que o fez esfaquear, com destreza, convicção e fúria, o seu imprudente senhor.

\footnotetext{
${ }^{65}$ AZEVEDO, Elciene. O direito dos escravos. Campinas: Editora da Unicamp, 2010. p. 85.

${ }^{66}$ JOHNSON, Paul Christopher; PALMIÉ, Stephan. Religiões afro-latino-americanas. In: ANDREWS, George; LA FUENTE, Alejandro de (org.). Estudos afro-latino-americanos: uma introdução. Ciudad Autónoma de Buenos Aires: CLACSO, 2018. p. 505-556, p. 510.
} 